\title{
References:
}

1. Скуратович I.M. Адміністративно-територіальний устрій України в 1920-1930-х рр. і його впливи на організацію державного управління: історико-правове дослідження. Х., 2004. 192 с.

2. Кулинич I.М., Кривець Н.В. Нариси з історії німецьких колоній в Україні. К., 1995. 272 с.

3. Німці в Україні. 20-30-ті роки ХX ст. Збірник документів державних архівів України/ Упорядн. Яковлєва Л.В. та ін. К., 1994. 242 c.

4. Центральний державний архів вищих органів влади та управління України (далі - ЦДАВО України). Ф. 1. Оп. 3. Спр. 2504. Арк. 118.

5. Збірник узаконень та розпоряджень Робітничо-селянського уряду України (далі - ЗУ УРСР). 1924. № 13. Ст. 130.

6. Итоги работы среди национальных меньшинств на Украине: К 10-й годовщине Октябрьской революции. По материалам Центральной Комиссии национальных меньшинств при ВУЦИК. Харьков, 1927. 167 с.

7. ЗУ УРСР. 1924. № 46. Ст. 279.

8. ЗУ УРСР. 1925. № 13-14. Ст. 99.

9. Вісті ВУЦВК. 1925. 7 травня.

10. Проблема районирования на Украине / Под ред. А.И. Буценка. Харьков, 1926. 158 с.

DOI https://doi.org/10.30525/978-9934-588-92-1-10

\section{ПОНЯТІЙНО-ПРАВОВЕ МИСЛЕННЯ У ДАВНІЙ ГРЕЦЇ̈: РАННЬОЕЛЛІНІСТИЧНИЙ СКЕПТИЦИЗМ}

\author{
Кучеренко Д. С. \\ консультант з юридичних питань \\ ТОВ «КОМРЕЦЬ» \\ м. Запоріжжя, Украӥна
}

Скептицизм (грец. skeptikos - той, хто розглядає, досліджує, мислить, сумнівається, від skeptomai - розглядаю, досліджую, мислю, сумніваюся) - філософський напрям, заснований Пірроном Елідським (бл. 360 до н.е.-бл. 270 до н. е.). До найвідоміших представників 
ранньоелліністичного скептицизму (III-I ст. ст. до н. е.) належать Тімон Фліунтський, Енесідем Кносський (пірронізм), Аркесілай Пітанський, Карнеад Киренський та ін. (академізм).

У скептичній філософії мислення ніби призупиняється 3 метою оглянути пройдений ним шлях і критично оцінити досягнення пізнання. На відміну від стоїків та епікурейців, які визнають позитивний критерій істини за допомогою якого можна обгрунтувати об'єктивне знання, скептики заперечують будь-яку можливість отримання такого знання. К. Маркс зазначає: «Они бросили выравнивающий, сглаживающий ученый взгляд на прежние системы и обнаружили таким образом противоречие и противоположность» [1, с. 209]. Основою скептицизму стає рівнозначна достовірність протилежних суджень (грец. izosteniya рівносильність). А наслідком ізостенії виступає утримання від судження (грец. еросһе̄ - затримка, зупинка, утримування, самовладання). Діоген Лаертський вказує: «...пирроновское рассуждение есть отчет о том, что кажется и каким-либо образом мыслится, вследствие чего все со всем соотносится, сравнивается и обнаруживает много неправильности и беспорядка... Показывая эти противоречия в рассмотрении, они на каждую убедительность предмета находят [другую] такую же, отменяющую ее. А убедительностью они считают то, что ...никогда или только изредка меняет свой вид, то, что принято обычаем, то, что определено законами...» [2, с. 357].

Скептики вважають, що якщо відчуття та розум окремо вводять людину в оману, тим більше можна очікувати помилкової думки від їхньої сукупної дії. Будь-якому аргументу може протиставлятися інший, не менш переконливий. Скептик сумнівається, чи дійсно явище є таким, яким воно нам здається. Скептицизм різко протиставляє догматичне знання (грец. dogma - думка; вчення), засноване на наукових даних i доведеннях, та феноменалізм (грец. phainomenon - те, що з'являється, явище), який спирається на те, що нам являється у суб'єктивному смислі слова та має нами сприйматися як чиста позірність. Згідно вчення скептиків ні про що взагалі нічого не можна сказати, оскільки все тече i змінюється. Всі говорять не про те, що дійсно $є$, а лише про те, що їм здається. Скептики за допомогою суб'єктивно застосованої гнучкості понять намагаються показати наскільки незначною є людська здатність знаходити вірну відмінність істинного від помилкового. Поєднання змісту сущого із мисленням на думку скептиків призводить не до істинного знання, а до знання ймовірного. Вони критикують стоїків, які вважають «осягнення» згодою буття і мислення, оскільки останні не зазначають критерію такої єдності. Згідно із скептичним вченням будь- 
який визначений зміст смислу має протилежністю інший визначений зміст, який також $€$ «істинним».

Г. В. Ф. Гегель так характеризує цей тип філософського мислення: «Скептицизм же в его подлинном смысле есть полнейшая безнадежность относительно всех тех определенных утверждений, которые рассудок считает незыблемыми, и возникающее в результате этого твердого убеждения умонастроение есть настроение непоколебимости и душевного покоя» [3, с. 209].

Критика пізнання за допомогою родових понять. Вже Сократ, Платон та Аристотель стверджують, що тільки у поняттях ми осягаємо істинну сутність речей. Так, наприклад, я пізнаю істинну сутність дерева не за допомогою наочного образу певного дерева, який я маю, а за допомогою родового поняття дерева загалом. Оскільки лише це родове поняття $\epsilon$ загальним для всіх людей, $\epsilon$ вільним від протиріч чуттєвого сприйняття, воно залишається незмінним і рівним самому собі. Скептики навпаки стверджують, що істину не можна виявити за допомогою родового поняття, тому що за допомогою цього поняття дерева я взагалі не пізнаю ніякої дійсності, оскільки йому не відповідає жодна реальність. Рід «дерево», яке я нібито пізнаю за допомогою родового поняття «дерево», не здатний до існування, тому що він містить у собі протиріччя. Можливе лише одне 3 двох: рід, що розпадається на види, містить у собі або всі підпорядковані йому види, або тільки деякі з них. Останне виключається, оскільки якщо рід «дерево» містить у собі лише сливу та платан, то каштан не належить до нього i, відповідно, не може бути загальним родовим деревом. Якщо рід містить у собі всі свої види, то рід «дерево», чи одволікле дерево, має містити всі сорти дерев. Проте це протиріччя, тому що його листя мало би бути й шпилястим i нешпилястим, воно мало би бути $\mathrm{i}$ листяним і хвойним, і великим і малим деревом. А виходячи із того, що кожне окреме дерево за сутністю є деревом, тобто належить роду, то кожному окремому дереву мають бути притаманними ці суперечні властивості, що $\epsilon$ абсурдним. У разі, якщо ми будемо стверджувати, що рід лише у можливості є слива, платан і каштан, то скептик відповість, що все, що є «дещо» у можливості, має бути і дійсним «дещо», у чому ця можливість існує. Що ж собою являють роди у дійсності? Якщо родове дерево не може бути ні сливою, ні каштаном, ні одночасно всіма сортами дерев разом, що ж воно таке? Адже можливості є можливими лише тому, що вони коли-небудь можуть стати дійсністю. Те, що є вірним відносно родів, $є$ вірним і відносно всіх загальних деяким речам властивостей, які можна пізнати - якщо тільки взагалі їх можна пізнати - лише за допомогою понять. Усе «загальне», що належить 
деяким, падає унаслідок внутрішніх протиріч, що йому властиві. До таких висновків призводить припущення про реальності, яким приписується не тільки індивідуальне, але й загальне існування, припущення про об'єктивне існування родових понять. Таким чином, скептики доходять висновку, що властивості дійсних речей ми так само мало можемо пізнати за допомогою понять, як i за допомогою відчуттів, оскільки поняття взагалі не належать до того, що дійсно існує. У кращому випадку тим, що існує у дійсності могли би бути роди та види. Проте скептики спростовують таку можливість у зв'язку із тим, що у родових поняттях ми не пізнаємо реальних об'єктів, і вони $\epsilon$ лише мисленим об'єднанням багатьох окремих речей, в якому ми зосереджуємо нашу увагу на загальних ознаках й одволікаємося від відмінностей.

Критика пізнання за допомогою визначень понять. Також скептики гостро ставлять питання про діалектику протилежних визначень філософського мислення, вказують на наявність у ньому протиріч $\mathrm{i}$ взаємовиключень. Вони, як вказує К. Маркс, сумніваються у можливості теоретичного обгрунтування будь-якого твердження: «...скептицизм есть профессиональное противоречие всяким мыслям, отрицание самого процесса определения» [1, с. 200-201]. Оскільки скептична свідомість виявляє все, що сприймається безпосередньо таким, яке не існує саме по собі, то скептики досліджують всі особливі визначення окремих наук. Так, у 156 році до н. е. Карнеад виголошує у Римі одну промову «за», іншу - «проти» справедливості, в яких розкриває протиріччя, пов'язані 3 одволіклим поняттям морального закону: «в оправдание справедливости он выставлял принципом всеобщее, а в своем доказательстве ее ничтожности он выдвигал принцип единичности, собственной выгоды» [4, с. 399]. Скептики заявляють, що ті, хто вважають, що за допомогою визначень можна дійсно краще пізнати речі, глибоко помиляються. Той, хто бажає щось пояснити, наприклад, людину, може пояснити цей предмет лише у тому разі, якщо він його знає. Лише тоді, коли він уже знає, що людина смертна та розумна, він може ії визначити, як смертну та розумну істоту. Таким чином, те, що пояснюється, осягається не за допомогою пояснення, а навпаки, останнє складається на підставі раніше пізнаних властивостей. Отже, я не пізнаю у визначенні нічого нового про властивості предметів, а тільки, так би мовити, розкладаю у ньому лише те, що мені вже відомо про ці предмети. Зрозуміло, що я не починаю знайомитися з окремими предметами за допомогою визначень, в яких я можу об'єднати мій пізнавальний матеріал. Властивості ж предметів я пізнаю науково подвійним чином. По-перше, я їх виводжу із загальних пізнань. По-друге, із окремих випадків я зводжу пізнання відносно 52 
властивості, що досліджується. При цьому, загальні положення не допоможуть мені пізнати конкретну властивість. Скептики заперечують проти цього способу пізнання та вказують, що зведення є або повним, або неповним. Якщо воно $\epsilon$ неповним, то воно ніколи не зможе обгрунтувати пізнання. У разі, якщо я не дослідив усі окремі випадки, то я не можу бути впевненим, що ця властивість дійсно належить певному роду, оскільки завтра мені може зустрітися окремий випадок, що спростує пізнання, побудоване на неповному зведенні. Таким чином, лише повне зведення може дати мені пізнання та істину. Але повне зведення неможливе, тому що існує безмежна кількість окремих екземплярів роду. Г. Гегель надає наступну оцінку досягненням скептицизму у пізнанні: «Требовалась удивительная сила отчетливой абстракции, чтобы во всяком конкретном материале, во всем мыслимом познать эти определения отрицательного или противоположения и в этом же определенном находить его же границу» [4, с. 440]. Проте поза увагою скептиків залишається дослідження єдності протилежностей.

\section{Література:}

1. К. Маркс и Ф. Энгельс. Из ранних произведений. Государственное издательство политической литературы, М. 1956. 699 с.

2. Диоген Лаэртский. О жизни, учениях и изречениях знаменитых философов / Ред. тома и авт. вступ. ст. А. Ф. Лосев; Перевод М. Л. Гаспарова. 2-е изд. М.: Мысль, 1986. 571 с.

3. Гегель. Энциклопедия философских наук. Т. 1. Наука логики. М., «Мысль», 1975. 452 с. (Акад. наук СССР. Ин-т философии. Филос. наследие).

4. Гегель Г. В. Ф. Сочинения: в 14-х т. / Г. В. Ф. Гегель; пер. с нем. Б. Г. Столпнер. Л.: Партийное издательство, 1932. Т. 10, Кн. 2. Лекции по истории философии. $454 \mathrm{c}$. 